Theory and Research in Social Education

Fall 2008, Volume 36, Number 4 pp. 317-355

(C) College and University Faculty Assembly

of National Council for the Social Studies

\title{
Facilitating Historical Discussions Using Asynchronous Communication: The Role of the Teacher
}

\author{
Wayne Journell \\ University of Illinois at Urbana-Champaign
}

This study examines the effectiveness of asynchronous communication in facilitating historical discussions among adolescents, with a specific focus on the ways in which teachers can affect this process. Threaded discussion board posts and teacher-student email correspondence from a five-week American history summer course are analyzed and triangulated with interview and observational data as part of a single case study. Using a social constructivist framework, the results suggest that the students in this particular course did not critically engage in discussions of a historical nature and often relied on unsubstantiated opinions that rarely challenged preexisting or canonical notions of history. The results also suggest that the teacher's actions or lack thereof may have contributed to the perfunctory social experience that students received. Although this study only serves as one example of $\mathrm{K}-12$ e-learning, the findings offer implications for teaching and learning social studies within online environments.

Until recently, online education was found almost exclusively in higher education. However, continued affordability of relevant technologies has allowed many $\mathrm{K}-12$ districts throughout the United States to adopt e-learning as an alternative to classroom instruction (Larreamendy-Joerns \& Leinhardt, 2006). Over 30 states have some form of web-based schooling program, and a growing number have established virtual high schools, either through funding from state legislatures or in conjunction with universities, in an attempt to ensure equitable educational opportunities for all students by offering advanced and elective courses to disadvantaged areas that may not have the necessary resources to offer such curricula (Blaylock \& Newman, 2005; Schrum, 2004). In 2007, the Michigan Department of Education took the unprecedented step of mandating that all students take at least one online course as part of their high school graduation requirements as a way to prepare students for the increasing demand for online education in postsecondary academia and business 
In addition, many secondary school districts have begun piloting their own e-learning programs as a way to increase flexibility for students who may need remediation, wish to graduate early, or balance academics with extracurricular or employment demands (Conceicao \& Drummond, 2005). While administrators laud e-learning as a lowcost method of educating large numbers of students (Burbules, 2004), critics remain skeptical of its instructional effectiveness (Noble, 2001; Postman, 2000). Moreover, research one-learning in K-12environments has focused predominantly on the ability of adolescents to succeed as independent learners (e.g. Kickul \& Kickul, 2006; Roblyer, 1999; Roblyer \& Marshall, 2002) rather than on e-learning as an appropriate medium for learning content.

This study moves beyond discussions of technological and motivational viability and focuses on the relationship between social studies and online instruction. Through a case study of an online U.S. history course I analyze the effectiveness of asynchronous discussion in facilitating historical discussions among high school students. Specifically, I focus on the role of the teacher in this process and how a teacher's expectations, participation, and specific instructional strategies can influence the quality of online interaction among students and between students and their teacher.

\section{Theoretical Framework}

Social constructivism is a theoretical framework in which reality is understood through social definitions developed through language, shared culture, and interpersonal relationship. (Schwandt, 1994). Elements of the world are interpreted by people, and the consensus of these interpretations constitutes reality. Social constructivists are less concerned about empirical justifications of knowledge than the process by which interpretations become reality (Berger \& Luckmann, 1966). Pedagogically, social constructivists argue that a fixed curriculum presents students with a distorted, one-sided view of reality. Instead, curriculum should be fluid, allowing students and teachers to interact and continually redefine the world in which they live (Gergen, 1995).

Social constructivism in education is tied to psychological theories of cognitive development in which social interaction aids in the negotiation and construction of knowledge (Fosnot \& Perry, 2005; Richardson, 2003). Much of this thought dates back to the work of Vygotsky (1978) and his theory of zones of proximal development, which he defines as "the distance between the actual developmental level as determined by independent problem solving and the level of potential development as determined by problem solving under adult 
guidance or in collaboration with more capable peers" (p. 86). While theorists have perceived zones of proximal development in multiple ways, a common interpretation states that collaboration with experts will increase cognitive ability when compared to learning alone (Lave \& Wenger, 1991).

Lave and Wenger (1991) argue that all learning is situated through social practice. There exists no set process for acquiring knowledge; instead, people learn through their relations with others. Therefore, the storage of information constitutes only a small portion of learning (Wenger, 1998). Using this communal stance on learning, Lave and Wenger distinguish between teaching and learning curricula. The former structures learning from an instructor's perspective and acquaints learners with predetermined salient knowledge. On the other hand, a learning curriculum adheres to the perspectives of learners and fosters opportunities for them to develop new practices. In this latter distinction, mastery of a subject does not reside in the master, but rather in the way the master has organized the learning community.

Too often, however, teachers believe constructivist pedagogy simply requires active or hands-on approaches to learning (Fosnot, 2005). Rather, a social constructivist classroom uses interaction to allow for the testing and challenging of beliefs, exploration of new domains, and interaction of curricula from meaningful contexts (Seixas, 1993). Teachers can foster these ideals by sharing curriculum decisions with students, acting as facilitators instead of purveyors of information, and providing opportunities for social and collaborative learning (Fosnot \& Perry, 2005; Gergen, 1995; Molebash, 2002; Richardson, 2003).

Within history education, a constructivist approach shifts the focus of learning from trying to find truth to searching for perspective (Doolittle \& Hicks, 2003). Early psychological research into the learning of history found that students approach history with preconceived constructions of historical reality (Wineburg, 2001). A social constructivist framework would emphasize the need to clarify these preconceived notions through social interaction, exploration, and negotiation (Doolittle \& Hicks, 2003). Teachers must convey the message that history is subject to interpretation and that two people may reach different conclusions even when presented with the same historical evidence (Lee, 2004; Wineburg, 1991).

\section{Importance of Classroom Discussion in Social Studies}

Discussions are a powerful instructional tool for constructivist pedagogy in social studies because it reinforces the teacher's role as a knowledge facilitator rather than a knowledge giver (Grant, 2003). In addition, Onosko (1990) found that social studies teachers who 
place a premium on critical thinking in their classes are more likely to use teacher-led classroom discussions on a regular basis. Conversely, teachers who place less emphasis on critical thinking employ lectures and textbook assignments as their primary instructional strategies.

Sadly, the incidence of discussion in social studies classrooms has waned in recent years, perhaps in response to the current era of high-stakes accountability that has consumed public education in the United States (Parker, 2006). A study by Nystrand, Gamoran, and Carbonaro (2001) of high school social studies classes found that $90 \%$ of all instruction was devoid of discussion, with the discussion in the remaining $10 \%$ lasting an average of 31 seconds. In addition, a recent survey of social studies teachers in Indiana found that while teachers recognize the instructional potential of classroom discussion, most defer to passive forms of instruction, such as lecturing, as their preferred method of delivering content (Bolinger \& Warren, 2007).

While many terms have been used in conjunction with classroom discussion, they all center around the idea of authentic discussion, which Hadjioannou (2007) describes as "a classroom-based speech genre in which participants commonly explore issues of interest by articulating ideas and opinions" during which "participants have opportunities to express opinions and ideas, and contributions are often built on ideas expressed by other participants" (p. 371). Parker and Hess (2001) further delineate classroom discussion into "deliberations" and "seminars." The goal of the former is to find a mutual resolution to a common problem, while seminars are "aimed at developing, exposing, and exploring meanings" with the primary goal to increase understanding of an issue or text (p. 282). Within social studies, the distinction between the two often blurs because seminars may naturally evolve into deliberations and teachers may purposefully use a seminar approach as background for a subsequent deliberation.

For any type of authentic discussion to be successful, Newmann and Wehlage (1993) argue that conversations among participants need to be substantive, which they define through three interrelated characteristics. First, substantive discussions require interaction about a topic that moves beyond reporting experiences and facts. Truly authentic discussions include higher-order processes such as "making distinctions, applying ideas, forming generalizations, [and] raising questions" (p. 10). Second, exchanges among participants are not scripted or strictly controlled. Instead, participants share ideas and ask questions of previous speakers. Finally, the dialogue among participants uses these shared ideas in a way that improves a collective understanding of the topic. In many cases, authentic discussions have no clear conclusion; therefore, the goal is to foster sophisticated understandings rather than attempt to objectify 
knowledge (Hadjioannou, 2007).

In addition, psychological research on classroom discussions supports their potential for encouraging students to think deeply about issues. The process of defending one's opinion requires that students constantly reconstruct existing schemas in order to organize one's thoughts, find flaws in others' arguments, and evaluate new information based on familiar notions (Reznitskaya \& Anderson, 2002). However, the development of argument schemas is a skill learned through practice and not something that students will be able to effectively master on the first try (Chinn \& Anderson, 1998). Teachers play an integral role in introducing and reinforcing effective discussion strategies among students, as well as monitoring classroom discussions when they occur (Anderson et al., 2001).

\section{Discussing Online: Social Studies, E-Learning, and Asynchronous Communication}

\section{Research on Social Studies E-Learning}

Although few studies have focused specifically on online instruction within K-12 history education, findings from social studies courses utilizing asynchronous discussion, which Bruce (2004) defines as "the exchange of messages in a medium that does not require simultaneous presence of the sender and receiver" (p. 21), suggest that threaded discussions have the potential to improve academic communication, particularly among older students. In a self-study of his college-level American history course, Lyons (2004) believed that the time allowed for reflection in asynchronous discussion created higher quality student responses. In another self-study, Merryfield (2000) found that threaded discussions allowed her graduate students to be more open and honest about their beliefs than they would have normally been in a classroom environment. Therefore, Merryfield argues that teachers can use asynchronous communication to foster substantive dialogue regarding typically sensitive topics such as diversity and social justice.

However, research on asynchronous discussion in $\mathrm{K}-12$ environments has yielded mixed results. In a study of classroom and electronic discussions in a high school social studies class, Larson (2003) found the two styles comparable, with each having advantages over the other. While students who actively contributed to classroom discussions also contributed heavily online, shy or minority language students who did not participate in the classroom increased their level of communication on the threaded discussion board. However, many students complained about the additional time needed to interact electronically, and most admitted to not reading all of their classmates' 
posts. One limitation of Larson's analysis in regard to the present study is that the electronic discussions took place in a computer lab with all of the students and their teacher present. On different occasions, the teacher would have to verbally tell students to move to a different topic on the discussion board because the students could not keep up with the rapid frequency of their classmates' posts. In a true asynchronous environment the students would not have had that immediate instructor feedback guiding conversations about content.

In a survey of students in an online world history course, Herring and Clevenger-Schmertzing (2007) found that students appeared to enjoy interacting with their peers on the course discussion board, but observation of the threaded discussion showed that students often did not post when they were not required to by their teacher. Moreover, once students had fulfilled their quota of required responses, they often turned their attention away from the discussion board and did not respond to further questions from the teacher or their peers. In addition, interacting on the course discussion board seemed to improve students' dispositions about history but did not appear to impact their academic performance. Students who participated regularly on the discussion board earned grades comparable to those who had minimal interaction, a finding supported by existing e-learning literature (Davies \& Graff, 2005).

\section{Role of the Teacher in E-Learning}

One popular conception of e-learning is that students will naturally adapt to asynchronous discussion given their penchant for recreational instant and text messaging (Larson, 2005). However; Tally (2007) cautions against making such assumptions and notes that many students may be adept at the commercial and entertainment aspects of the internet but have difficulty making academic use of technology. Therefore, teachers play an important role in preparing and monitoring online instruction, particularly when dealing with adolescents.

Studies chronicling students' experiences with e-learning report that students view their instructors as integral to their educational experience (Chyung \& Vachon, 2005; Dewstow \& Wright, 2005). In their study of an online world history course, Herring and ClevengerSchmertzing (2007) found that student interaction with their teacher appeared even more important than interaction with their peers. Another study by Kapitzke and Pendergast (2005) found that students prefer e-learning teachers who employ a variety of pedagogical strategies, even if they are not as technologically savvy as colleagues who utilize transmission of information as their primary instructional method. In other words, the characteristics of exceptional classroom 
teachers follow suit in an online format.

A primary concern of teachers in a social constructivist environment, whether online or in the classroom, is how to prompt and shape the nature of community interaction (Berge, 2002, 2005; Gergen, 1995). Larson (2005) contends that "teachers who use threaded discussions can monitor how students are thinking about subjects, and can, as a result, guide students toward sound, factbased analyses" (p. 162). However, the ways in which teachers monitor asynchronous discussions may influence students' levels of participation and willingness to engage in academic conversations with others. For example, in a case study of an online graduate course, Maor (2003) found that teacher interaction and modeling within a discussion board aided in the quality and thoughtfulness of posts, although she warns that too much interaction has the potential to stifle student conversation. Similarly, Hazari (2004) suggests that instructors should interject only when necessary to clarify points. Teachers should instead provide explicit directions regarding participation in collaborative assignments, which Hazari posits will increase the likelihood of quality discussions. Finally, Rovai (2001) observed that required participation seems to aid in the development of online communities, in part by reducing the number of "lurkers," students who monitor the online activities of others yet rarely give substantial feedback to the community (Haythornthwaite \& Bregman, 2004; Rovai 2000).

However, secondary e-learning teachers often express frustration over losing control of asynchronous discussions because students can choose to ignore teachers' posts as opposed to in the classroom when they "have to listen" (Larson, 2005). Part of this frustration may stem from the fact that most secondary e-learning teachers often have to resort to trial-and-error since few universities offer training in online instruction as part of their teacher education programs (Davis \& Roblyer, 2005). A common practice among school districts is to place exemplary classroom teachers in online environments; however, many teachers find that even though effective instructional strategies often work in both mediums, the instructional specificity and attention to student responsiveness required of successful teaching often increases when teachers lose the nonverbal component found in the classroom (Garrison \& Anderson, 2003; Maor, 2003).

\section{Context of the Study}

The study took place in 2007 over a two-month summer session in a Southwestern Virginia school district that comprises nearly 15,000 students. The district would be categorized as predominately suburban with approximately $10 \%$ minority enrollment and $19 \%$ 
of students eligible for free and reduced lunch. The district boasts a $98 \%$ graduation rate and maintains a solid academic reputation. In recent years, the district has gained recognition for its dedication to educational technology, implementing an initiative to increase the number of personal computers available to students in the classroom.

At the time of the study, the district e-learning program had been in existence nearly five years. Developed initially as a method of instruction for students unable to attend school for medical or social reasons, the program has grown in popularity each year, with enrollment increasing 15\% annually. Students have the option of taking Blackboard courses in U.S. History, U.S. Government, English 11 \& 12, Pre-Calculus, Health I \& II, and Ecology. Although the district offers online courses concurrently with the regular school year, the largest enrollment occurs during summer school. The summer in which I conducted the present study, over 200 students signed up for virtual courses. The selection of this particular program for study was purposeful based on previous knowledge of the program and reputation of the district.

Thirteen of those students enrolled in U.S. History, representing each of the district's five high schools. Seven of the students were male and six were female; all of the students were white. The majority of the students were rising juniors, although one student had just finished her freshman year and another had completed his senior year and needed to pass the course to officially graduate. Five of the students were taking the course to graduate early and four students wanted to free up their schedules for the subsequent school year. Another student was taking the course as a solution to scheduling problems that occurred after transferring from another state. Only one of the students, Ryan, ${ }^{1}$ claimed history to be his favorite subject, although only three admitted to not liking social studies at all. The rest of the class gave lukewarm responses that ranged from not recognizing the usefulness of history to their future plans to complaining about poor. grades received in prior history courses. All of the students passed the course, and the grade distribution was fairly even with three students earning A's, four earning B's, and three each earning C's and D's.

All of the online courses were taught by district teachers. Mr. Harding, a teacher with over 10 years of experience in the classroom, had been assigned the responsibility of designing the district's online U.S. History course. He had taught the online course six times over the previous three years. Mr. Harding had earned undergraduate and masters' degrees in history education and had also received training in Advanced Placement (AP) curricula, which he taught exclusively during the regular school year. Mr. Harding taught the online course as a way to earn extra money over the summer while still being able 
to travel and spend time with his family. In many ways, Mr. Harding was typical of the type of teacher utilized in the district's e-learning program. Due to the relative newness of the program, many of the teachers who designed the courses were still the ones assigned to teach them on an annual basis. Mr. Harding also represents the district's tendency to provide opportunities for online instruction to classroom teachers who demonstrate a willingness to integrate technology into their teaching. In that sense, the selection of Mr. Harding for study was purposeful, although he was the only online history instructor employed by the district.

For the district and Mr. Harding, the purpose of the course was to acquaint students with a survey of U.S. history that covered all of the required Standards of Learning (SOL) and provided instruction equivalent to what students would receive during the normal school year. To achieve these goals, Mr. Harding divided the course into 12 units corresponding to traditional chronological divisions in U.S. history. In order to maintain consistency, Mr. Harding required students to complete four identical tasks in each unit, starting with SOL content that was subsequently reinforced through written assignments, discussion board responses, and a multiple choice assessment. $^{2}$ Participation in the discussion board was required, although no clear guidelines for an appropriate level of participation were given on the course syllabus. The weight of the discussion board grade varied by unit based on its complexity relative to the other unit components, but it was usually worth $10 \%$ of each unit grade.

The course ran approximately five weeks and, on average, students had two days to complete each unit. In addition to the twelve units, students had both a midterm and final exam requirement, which were taken in person at a designated site and proctored. These exams counted for $20 \%$ of their respective semester averages. Students also took an SOL assessment that did not count into their course grade, but which they needed to pass in order to receive verified credit for the course.

\section{Research Questions}

While all aspects of the course potentially affected students' perceptions of history, the focus of this study is on the social component of the course. Specifically, I am focusing on the role Mr. Harding played in structuring and monitoring asynchronous communication among his students and between himself and his students. Therefore, the research questions driving this study were: a) How effective is asynchronous discussion in facilitating substantive historical discussions among adolescents? b) What factors appear to affect the quality of historical discussions within an asynchronous format? and c) What is the role of the teacher with respect to these factors? 


\section{Methodology}

I utilize what Stake (1995) and Merriam (1998), respectively, call an instrumental or particularistic case study design, in which I examine a specific case in order to provide insight into a particular issue. Case studies, according to Yin (1994), are optimal for "examining contemporary events, but when the relevant behaviors cannot be manipulated" (p. 8). In other words, they allow the researcher to observe phenomena within their natural setting, or bounded system (Merriam, 1998; Stake, 1995). In the present study, the asynchronous communication utilized in the course, specifically the course discussion board, serves as the case being studied.

Thegoal of case studies, then, is transferability, notgeneralizability (Donmoyer, 1990; Lincoln \& Guba, 1985). While the interpretive nature of case studies precludes replication, if similar elements of one case are shared by another, then the researcher can make assumptions about the nature of phenomena in a similar context.

\section{Data Sources}

Data came primarily from teacher and students' exchanges on the course discussion board. At the conclusion of each unit, I analyzed the hierarchy of each discussion thread and noted the number of original posts and replies made by Mr. Harding and each of his students. I then printed each of the individual posts for coding and further analysis.

In order to better understand the teacher's role in the instructional process, I engaged in semistructured interviews (Merriam, 1998) with Mr. Harding. I conducted an initial interview with Mr. Harding prior to the start of the course. I maintained contact via email throughout the duration of the course, asking questions regarding instruction and student activity as needed. The initial interview served to understand Mr. Harding's teaching philosophy, instructional goals, and beliefs on student interaction. I asked him questions about his attitudes toward e-learning and how he perceives high school students who take online courses. The interview concluded with Mr. Harding explaining his strategies for maximizing social interaction in the online course (Appendix A). The initial interview was audiotaped and transcribed for accuracy. Although I did not analyze the interview transcription with Mr. Harding, I did refer to his responses on several occasions when I emailed him with additional questions throughout the course.

In addition, I examined all email communication between Mr. Harding and his students throughout the duration of the course. Mr. Harding forwarded me all email sent to him from students and copied me on any emails he sent to the class or individual students. I also took fieldnotes at the district-mandated face-to-face orientation session held prior to the start of the course where Mr. Harding outlined the 
course structure and expectations.

Finally, additional data sources came from more structured (Fontana \& Frey, 2005) interviews with the district e-learning coordinator $^{3}$ and 11 of the 13 students $^{4}$ in the course. The e-learning coordinator interview was held prior to the start of the course, and the student interviews were held prior to the midterm exam (Appendix B). The focus of these interviews was to gain background information on the e-learning program, administrative opinions of Mr. Harding, and student reactions to the discussion board and the course in general. All interviews were audiotaped and transcribed for accuracy. These sources were used collectively to maximize the interpretive validity of the case by trangulating, or confirming, evidence (Maxwell, 1992).

\section{Data Analysis}

Data from this case study were analyzed using an interpretative methodology (Crotty, 1998; Schwandt, 1994, 2003). For the discussion board, I coded each statement based on whether the statement substantively promoted authentic historical discussion, adapting a coding scheme from Davidson-Shivers, Morris, and Sriwonkol's (2003) work on gender differences in online communication. In cases of missing or erratic punctuation, I considered indications of new thoughts as individual statements. Within both the substantive and non-substantive categories, I created subcategories to further delineate the statements. I considered substantive statements those that used historical evidence, actively agreed with others' posts, posed questions to others, directly responded to questions posed by others, or disagreed with or challenged others' beliefs. I labeled statements as non-substantive that expressed unsubstantiated opinions, offered simple encouragement, passively agreed with others' posts, or provided recreational banter. Table 1 provides examples of statements that would fall within each category.

For the email communication, I categorized each email by topic. A total of 111 emails were exchanged between Mr. Harding and his students. The email fell into one of four categories: technological, procedural, recreational, and historical, with each category containing relevant subcategories (e.g. Frustration with Technology, Class Announcements).

All interview and observational data were analyzed for any apparent influences on the development of historical thought on the discussion board. This information was then triangulated with discussion board and email data to paint a more comprehensive picture of the case. In the subsequent sections, I present the results of my research. First, I portray the quality of the student discussion in the asynchronous environment, and then I address how Mr. Harding 
may have played a role in shaping his students' ability to engage in substantive dialogue.

Table 1

Coding Scheme for Discussion Board Posts

Substantive Statements

Use of Historical Statements that

Evidence (HE) support claims with evidence learned in the course

Active

Agreement (AA)

Statements that agree with others and explain why or offer clarification

Statements that ask for clarification or opinions from others

Question to Others (PQ)

Responses to Questions (RQ)

Disagreement/ Challenge Beliefs (D)
Statements that directly responded to questions from others

Statements that either disagreed or challenged others' beliefs
Ex: The South lost the Civil War because of their lack of supplies, eventually resorting to throwing rocks at Union soldiers.

Ex: I agree that Lincoln helped the Union win; the Emancipation Proclamation helped turn the tide of the war.

Ex: Why do you think dropping the atomic bombs saved lives?

Ex: Yes, I think Lincoln's assassination hurt

Reconstruction.

Ex: I disagree that Slavery was the cause of the Civil War; the agriculture of the South forced them to have slaves.

Non-Substantive Statements

Unsubstantiated Statements that

Opinions (UO) expressed opinions without any historical evidence

Encouraging

Remarks (ER)

Passive

Agreement (PA)

Recreational (R) Statements that are off topic to motivate with others without clarifying why
Ex: I believe WWII was the most important event of the century.

Statements intended Ex: Good job, Cynthia!

Statements that agree

Ex: I agree with everything you said.

Ex: Sorry my post was so long! 


\section{Quality of Student Discussions}

\section{Unequal Participation}

One issue that seemed to affect the quality of historical discussions during the course was unequal participation with regard to the number and detail of student posts. Table 2 highlights the difference in the number of total posts, replies to classmates, and total statements made by students in the course.

Table 2

Student and Teacher Discussion Board Participation

\begin{tabular}{lccc}
\hline & $\begin{array}{c}\text { Total Number } \\
\text { of Posts }\end{array}$ & $\begin{array}{c}\text { Number of } \\
\text { Replies }\end{array}$ & $\begin{array}{c}\text { Total Number of } \\
\text { Statements }\end{array}$ \\
\hline Amy & 19 & 8 & 126 \\
Beth & 2 & 0 & 26 \\
Cynthia & 46 & 35 & 370 \\
Jennifer & 35 & 29 & 219 \\
Nicole & 10 & 6 & 69 \\
Rebecca & 5 & 1 & 34 \\
Allen & 38 & 27 & 156 \\
Bill & 11 & 1 & 55 \\
Brandon & 32 & 21 & 232 \\
Hunter & 14 & 4 & 73 \\
Jason & 14 & 3 & 85 \\
Pete & 13 & 4 & 53 \\
Walter & 18 & 7 & 155 \\
Mr. Harding & 17 & 16 & 41 \\
Total & 274 & 162 & 1694 \\
\hline
\end{tabular}

Four students, Cynthia, Jennifer, Allen, and Brandon, appeared to carry the conversation both in terms of quantity and substance. Walter and Amy comprised a second tier of participation; both students made considerably fewer posts than the four previously mentioned students, but the total number of statements in their posts suggests that they took care to produce lengthy responses. The rest of the class minimally interacted on the discussion board, and when they did, their responses were often brief. 
These differences can be seen in the quality of individual posts. For example, consider Hunter's response to a prompt questioning American involvement in World War I:

I think the US did the right thing being aggressive. If they would not have done what they did the US probably would not have grown to be so strong. I believe, that they did the right thing when they sent troops to Europe. I believe that sooner or later we would have been in World War I and I think that we saved ourselves a lot of threats to our country by going in. The power of the US army would have not been with the Allies. I just think that we would have suffered big time if we went into the war any later.

Then, compare his response with a mere excerpt of Cynthia's response to the same question:

Then with WWI the US first off did try to stay out of the war with Wilson's declaration of neutrality but when their old comrades in Britain and England were being attacked it made it very hard. After all, despite the fact that the US had separated themselves from England and Great Britain many years earlier, the US's connection with them was still very strong because in addition to their long history/ancestry the US also had very strong cultural and economic ties with both Great Britain and England making the US want to help out their old allies in any way they could. Another big factor, probably the most important, was the fact that American ships were getting attacked by Germany, who maybe were just trying to keep the US out of the war, but they had a horrible way of doing it because how can any nation that is supposed to protect its people just sit back and let something like the purposeful sinking of the Lusitania, which killed over 1,000 people may I add, go unnoticed? They can't! The US had to take up some kind of defense against this sort of action and besides when the US was actually being singled out it no longer made the war and even the people were behind the nation joining the war.

Despite Cynthia's apparent confusion over Great Britain and England being the same nation, one can see how her post provides a more convincing historical argument than Hunter's. While Hunter does hint at German aggression prior to American intervention into World War I, Cynthia focuses on submarine attacks and lists the famous example of the Lusitania. Cynthia also expresses her opinion on U.S. involvement in World War I through an analysis of the relationship between the 
United States and Britain, as well as her rationale that a nation must protect its citizens, even if that means going to war. Hunter chooses to personalize his opinions without providing sufficient evidence to support his claims, instead using vague terms such as "suffering big time" to justify his position.

In addition, the student interaction often lacked depth. Although the slavery unit, which will be discussed later, contained several complex threads, the other 10 units combined only contained one tertiary response, meaning that the original poster revisited the discussion board and responded to comments regarding his or her initial post. This one instance occurred between Cynthia and Mr. Harding during the Reconstruction unit when Mr. Harding asked for clarification regarding Cynthia's opinion on the impact of Lincoln's assassination. Although 9 of the 11 students interviewed stated that they did go back to the discussion board to see if others replied to their posts, the majority of students seemed disinterested in continuing conversations with others.

Table 3

Analysis of Non-Substantive versus Substantive Statements

\begin{tabular}{|c|c|c|c|c|c|c|c|c|c|}
\hline \multirow{2}{*}{. } & \multicolumn{4}{|c|}{ Non-Substantive } & \multicolumn{5}{|c|}{ Substantive } \\
\hline & $\mathrm{UO}$ & ER & $\mathrm{PA}$ & $\mathrm{R}$ & $\mathrm{AA}$ & $P Q$ & $\mathrm{D}$ & $\mathrm{HE}$ & RQ \\
\hline Amy & 72 & 0 & 3 & 0 & 1 & 1 & 8 & 41 & 0 \\
\hline Beth & 5 & 0 & 0 & 0 & 0 & 0 & 0 & 21 & 0 \\
\hline Cynthia & 169 & 0 & 32 & 3 & 11 & 3 & 11 & 140 & 1 \\
\hline Jennifer & 115 & 1 & 22 & 1 & 10 & 1 & 6 & 63 & 0 \\
\hline Nicole & 28 & 1 & 5 & 0 & 5 & 0 & 1 & 29 & 0 \\
\hline Rebecca & 24 & 0 & 0 & 0 & 0 & 1 & 0 & 9 & 0 \\
\hline Allen & 57 & 1 & 23 & 7 & 3 & 2 & 13 & 50 & 0 \\
\hline Bill & 40 & 0 & 5 & 1 & 0 & 1 & 0 & 8 & 0 \\
\hline Brandon & 86 & 1 & 29 & 0 & 7 & 8 & 7 & 94 & 0 \\
\hline Hunter & 52 & 0 & 0 & 0 & 0 & 1 & 2 & 18 & 0 \\
\hline Jason & 51 & 0 & 2 & 0 & 1 & 1 & 3 & 27 & 0 \\
\hline Pete & 31 & 0 & 1 & 0 & 1 & 2 & 1 & 17 & 0 \\
\hline Walter & 98 & 0 & 7 & 0 & 4 & 0 & 6 & 40 & 0 \\
\hline Mr. & 1 & 18 & 1 & 1 & 2 & 12 & 1 & 5 & 0 \\
\hline \multirow{3}{*}{$\begin{array}{l}\text { Harding } \\
\text { Total }\end{array}$} & & & & & & & & & \\
\hline & 829 & 22 & 130 & 13 & 45 & 33 & 59 & 562 & 1 \\
\hline & \multicolumn{4}{|c|}{$\begin{array}{l}\text { Total Non- } \\
\text { Substantive: } 994\end{array}$} & \multicolumn{5}{|c|}{ Total Substantive: 700} \\
\hline
\end{tabular}

Note. Non-substantive and substantive subcategories refer to those found in Table 1. 


\section{Lack of Historical Substance}

Even when students did participate in the discussion board, their attempts at engaging in historical dialogue often lacked substance. The coding of individual posts found that non-substantive statements were used more often than substantive statements, and students relied predominantly on unsubstantiated opinions to support their positions. Table 3 lists the coding results for each individual. Perhaps more disturbing from a social constructivist standpoint is the lack of disagreement or challenging of beliefs that leads to multiple perspectives of history. The dialogue that occurred in the discussion board appeared to center on passively agreeing with others' responses and ignoring new ideas or calls for clarification.

The following thread ${ }^{5}$ from the Jacksonian Unit is indicative of the type of interaction found throughout the course. Students were asked to place themselves in President Jackson's shoes and give their opinion on how best to regulate Westward expansion:

Jennifer: I would try to make a deal with the Indians and Mexicans. Let them live where they want and let Americans live in the other places, or see if they could live together peacefully. After all, if you prohibit people from moving west, they would think that it was too much like the British Government that they fought to get away from. And, it is inhumane to force Indians and Mexicans from their homelands, where they have lived for centuries. As president, I would set up punishments for anyone who were cruel to the natives. It would not be a good idea to stop Americans from westward expansion, because otherwise the East would become overpopulated, and there would not be many economic opportunities for the citizens. I would just try to limit the amount of people who did move west, and set up settlements where they could live and not disturb the Indians.

Allen (to Jennifer): I agree that you should try to make a deal with them, or try to live peacefully with them, and that it's inhumane to try to force them out of their homeland.

Brandon (to Jennifer): I agree with what you are saying. I would try to help the Indians and Mexicans without making them move out of their home lands. I think that is wrong. As President $\mathrm{i}$ would have done exactly what you are thinking.

Walter (to Jennifer): I agree. I especially thought you made 
a good point when you pointed out that the East would be overpopulated. I also agree with your statement "I would just try to limit the amount of people who did move west, and set up settlements where they could live and not disturb the Indians".

Cynthia (to Jennifer): I completely agree with you especially about trying to work it out and also about the east become overpopulated.

Jennifer's initial post clearly stated her opinion and even evoked prior knowledge of American-British relations, perhaps referencing the Proclamation Line of 1763 . However, all of the replies simply regurgitated her opinions without questioning the inherent problems that may have occurred without governmental regulation of Westward expansion.

Another thread from the same prompt highlights a different impediment to historical discussion:

Allen: It would be a tough decision, (I don't know why I would be president anyway lol) but I would probably still let them continue to go west, however, I would tell them to try and go around the Native American Indians if possible, and absolutely no fighting or pushing them out of thier homeland, or they would suffer the same consequences as if they did that to any other American. I would tell the people that they have more of a right to be here than we do, because they were here first, and even though they were different and did not live with us and were in thier own tribes, they still had rights, and if we broke them, we were no different than the British trying to break our rights.

Walter (to Allen): I agree with your statements and the points you made. However I know everyone, including myself, is stating that they would make the Settlers go around or be humane to the Native Americans. It is hard to tell settlers to be humane to Native Americans but to be inhumane towards their own slaves. At that time period it seems that everyone different from the settlers, even different groups of settlers were viewed as different and inferior. People felt like they could treat people who were different than they were as inferior.

Jennifer (to Allen): I agree with that, it does sound a lot like the British trying to limit our rights.

In this instance we have Allen advocating his plan for Westward 
expansion, which relies on avoiding conflict with Native American tribes whenever possible. Then Walter raises a sophisticated point regarding the tendency of his classmates to advocate humane treatment for Native Americans while ignoring the fact that many whites in the South owned and mistreated African American slaves during this time period. Walter's post broaches the idea of historical understanding by shifting the conversation from a stance rooted in presentism to a critical analysis of life during the early $19^{\text {th }}$ century. Unfortunately, his efforts were in vain since no one attempted to respond to his query. The lone person to contribute to this thread after Walter's post, Jennifer, chose to passively agree with Allen's comment rather than engage Walter and continue the conversation. Jennifer's actions suggest that she may have chosen to read Allen's initial post and respond without reading the entire thread up to that point.

Other evidence suggests that students did not attempt to read a majority of the posts. Referring back to Table 3, even when removing Mr. Harding's 12 questions posed, his students asked 21 questions on the discussion board during the span of the course, and none of them were ever answered. The only response to a question occurred during the aforementioned exchange between Cynthia and Mr. Harding in the Reconstruction unit. The student interviews also served to confirm this assertion. When asked how many posts they read per unit, none of the students claimed to read all of their classmates' posts. Five students admitted to reading less than five posts per unit; other responses ranged from "about half" to "everyone's initial post."

\section{Teacher Influence on Discussion Board Interaction}

\section{Course Management and Participation}

Based on discussions of his teaching philosophy, Mr. Harding appeared to recognize the value of student interaction from both a social and academic perspective. As he stated,

I think that most students, including myself, will forget the vast majority of information that you learn in the classroom, the rote memorization, which means ultimately, maybe you have a short term goal that is accomplished or achieved, but for the long term, academics are largely meaningless ... I don't think the vast majority of my students are going to remember, I don't know, pick out a battle - the Battle of Antietam, let's say-10 years from now. Not a big deal, you know? Now I understand academically, they are learning a variety of things, like you know, memorization and time management and all of those sort of things, but I think that academically the short-term goals of, 
that illustrate that they have learned $X$ amount of information is largely worthless in the long term. Socially, on the other hand, if they can become confident in themselves, if they can ascertain where their strengths and weaknesses are, if they will socially come out in the classroom and interact with others in a productive way, then that, to me, far exceeds the value of academics.

Mr. Harding claimed these beliefs transferred from the classroom to online instruction, but he appeared skeptical of the ability of e-learning to foster a comparable level of interaction. When comparing his classroom to the online course he stated, "the biggest drawback [of e-learning] is simply, you know, probably that social environment. I just don't think it's there." However, Mr. Harding did include discussion board activities in nearly every unit and acknowledged that the discussion board provided opportunities for students to frequently interact, provide input to each other, express their opinions, and make judgments on historical issues. Yet, Mr. Harding perceived the asynchronous discussion as perfunctory when compared to the "magic of the classroom, where you respond to the moment, when a kid's facial expression, the nonverbal expression, is the key to taking the next step."

Mr. Harding also felt his online students did not desire to interact socially. Based on his previous online teaching experiences, he compared e-learning students to the bottom $10 \%$ of his classroom students that "come in, take their seats, they're quiet, they give you one word answers, and they are out the door." Moreover, Mr. Harding believed that the online course better suited those without a keen interest in history. He argued that "For the kid that wants to get as much out of the history as possible and finds things interesting and wants to connect past and present... it's a great place in the classroom, not a good place online."

These perceptions of e-learning and online students may have influenced the way Mr. Harding managed and participated in the online course. Prior to the start of the course, Mr. Harding stated that he felt he had to "really force the discussion board interaction. I have to force the discussion and the comments. And it almost always falls short of what I hope and anticipate to get." Yet, Mr. Harding's actions before and during the course seemed to contradict this statement. For example, he never set a required number of student posts per unit. Instead, during the orientation session, he simply explained the purpose of the discussion board and encouraged students to interact with each other and engage in historical discussions. However, the range of the number of posts and statements listed in Table 2 suggests that his students held differing ideas of what constituted an 
appropriate level of participation.

In addition, when asked if he instituted minimum word requirements on students' discussion board posts, Mr. Harding replied,

I have not done word limits, I didn't think I would have to. I am finally realizing that I need to do that. I model the behavior in the orientation, but what I see is that almost always some kids will meet the expectations, but most kids will immediately start falling back, giving me, you know, two to three sentence answers. You know, I am looking for deeper stuff.

A week later at the orientation session, Mr. Harding did give students a guideline of 250 words for each initial discussion board post. However, this requirement was not listed on the syllabus or on any of the individual discussion board assignments, nor was it reinforced by Mr. Harding throughout the course. Of the 13 students in the class, only Cynthia and Brandon routinely met this standard.

Prior to the course, Mr. Harding also stated that he routinely gave feedback to students online, comparing the nature of the feedback to what students would find in the classroom. He described this feedback in the following way:

I am directing their learning. I am giving them feedback. I am giving them encouragement, or discouragement if they don't do a good job on it. I will answer their questions, so you see a very similar role between the classroom and the computer, you know, online environment.

Mr. Harding clarified his comments by saying that he does not feel he interacts with his online students as much as his students during the regular school year. Moreover, he appeared skeptical that his online students took the time to read the feedback that he did provide them.

While Mr. Harding may have routinely provided feedback to students when he returned homework and projects, his feedback within the discussion board occurred primarily at the start of the course with only a handful of comments occurring after the second unit. During the first unit, Mr. Harding replied to nearly every student's initial post, offering praise for a well articulated response and questioning or asking for clarification when necessary. The following is Mr. Harding's response to Pete in that first unit:

Good start Pete! Cities in the North and farming in the South... definitely a long term effect of Colonization. What about race relations? Can you see that connection? How about the issue of 
morality and the Puritans? Natural rights? Keep going on this one...

These comments and similar ones made to others in the class appeared to ask students to return to the topic and elaborate on their thoughts or even engage in a dialogue with Mr. Harding. However, neither Pete nor any of his classmates responded to any of Mr. Harding's posts in that first unit.

After making four posts in the second unit, Mr. Harding only made four additional posts during the rest of the course. Three of those posts were to Cynthia, who regularly provided the most detailed and lengthy posts in each unit. Only once did Mr. Harding post his thoughts regarding the question posed in a particular unit. This occurred in the Jacksonian unit and acted as a summary of the discussion to that point. He stated,

Ok-you have made some good points. Look especially at Cynthia's summary of the problem. On one hand, you are the US President. Remember how Americans perceived Indians at this time-they were considered to be savages. You need the land. If you don't take it, someone else will. Northerners and Southerners each want to go West-for different reasons. On the other hand, the Indians were there first. They are entitled to their land. What do you do? It is a real problem...Y You can't please everyone all the time...

In addition, Mr. Harding did not seek to involve himself in his students' social conceptualization of history. As Table 3 shows, Mr. Harding never attempted to answer any of the 21 student questions that were posed throughout the duration of the course. This inaction contradicts his earlier statement regarding student feedback and suggests either an unwillingness to engage in his students' discussions or poor monitoring of the discussion board interaction.

Mr. Harding's decline in discussion board participation was not due to satisfaction with the quality of students' posts. In fact, Mr. Harding appeared despondent about the progress made by the majority of the class. In an email shortly before the midterm exam, Mr. Harding wrote the following when I asked for his reaction to the discussion board participation thus far:

It is frustrating for me. Cynthia, Walter, and Jennifer are making good use of the course. Brandon and Allen are a step down... but, still getting something out of the class. The others are at various levels of just easing through. My biggest frustration with myself is the lack of ability/commitment to interacting with them on the dboards. 
Mr. Harding appeared to share the blame for what he considered poor participation in the discussion board. Although Mr. Harding expressed regret for not actively interacting in class discussions in this email, he did not increase his level of participation in the second half of the course.

\section{Lack of Communication}

Although Mr. Harding appeared to excel at the administrative tasks of teaching online, there seemed to be a considerable lack of communication between Mr. Harding and his students regarding content and the nature of historical discussions. For example, the quality of student discussion remained steady, with few exceptions, over the span of the course even though length and substance of posts factored into students' discussion board grades. This suggests that those students producing lower quality posts and receiving poor grades either did not know why their discussion board grades were docked or simply did not care. An email response from Mr. Harding to a parent who questioned his son's discussion board grade lends evidence to the former, at least for some students:

$\mathrm{Hi}$ again. In regard to the discussion boards on Blackboard, tell Brandon to take a look at Cynthia's comments for the last couple of units. She is consistently earning the highest marks. You should not judge Brandon by the other students. Most of the class members are not earning as high a grade as Brandon (on discussion board responses). He simply needs to add in more facts; to give more thought and insight into the answers. Even Cynthia is not giving me quite as much as I would like. However, she is setting the bar for the rest of the class.

This email suggests that Brandon, or at least his parents, viewed the discussion board in relative terms. However, even though Brandon regularly submitted longer and more substantive posts than the majority of his classmates, he failed to meet Mr. Harding's expectations of a quality discussion board post. In other words, Mr. Harding appeared to maintain high standards for students throughout the course, yet students' posts reflected the possibility that they may have been unaware of these standards.

In addition, the email data reveal that Mr. Harding did not attempt to answer student questions or start historical discussions with students outside of the discussion board. Table 4 shows the breakdown of the 111 emails sent between Mr. Harding and his students over the five-week course. Email communication centered 
on problems with technology or course procedures. Only two emails dealt with American history, a question posed by Cynthia regarding the timing of Turner's Rebellion and Mr. Harding's response.

Table 4

Description of Email Sent between Mr. Harding and his Students

\begin{tabular}{lccc}
\hline & $\begin{array}{c}\text { From Mr. } \\
\text { Harding to } \\
\text { Students }\end{array}$ & $\begin{array}{c}\text { From } \\
\text { Students to } \\
\text { Mr. Harding }\end{array}$ & Total \\
\hline Technical Emails & & & \\
\hline $\begin{array}{l}\text { Alerting of a Problem } \\
\text { Acknowledgment or }\end{array}$ & 25 & 9 & 16 \\
$\quad \begin{array}{l}\text { Solution } \\
\text { Frustration with Technology }\end{array}$ & 0 & 17 & 27 \\
\hline Procedural Emails & & & 17 \\
\hline $\begin{array}{l}\text { Scheduling or Assignment } \\
\text { Clarification }\end{array}$ & 7 & 9 & 16 \\
$\quad$ Student Progress & 16 & 10 & 26 \\
$\quad$ Class Announcements & 2 & 0 & 2 \\
\hline Recreational Emails & & & \\
\hline Sharing Informal & 0 & 2 & 2 \\
Information & & & \\
$\quad$ Cordial Responses & 3 & 0 & 3 \\
\hline Historical Emails & & & \\
\hline$\quad$ Historical Inquiry & 0 & 1 & 1 \\
\hline Historical Answers & & 0 & 1 \\
\hline
\end{tabular}

\section{Inclusion of Primary Sources}

The discussion board contained one departure from the simplistic dialogue exhibited throughout the course due, perhaps in part, to $\mathrm{Mr}$. Harding's decision to provide students with primary sources and encourage them to engage in a mock debate. In the slavery unit, Mr. Harding randomly divided the class into Southern plantation owners and Northern abolitionists and had the groups debate the merits of slavery based on their antebellum roles. Mr. Harding also gave each side several primary sources (Appendix C) from which they could garner ammunition for their arguments and told his students that he 
expected a lively debate.

The slavery forum garnered considerably more total posts, replies, and substantive statements than any other unit. Table 5 displays the differences among the units.

Table 5

Number of Non-Substantive and Substantive Statements by Unit

\begin{tabular}{lccc}
\hline & $\begin{array}{c}\text { Non- } \\
\text { Substantive (-) }\end{array}$ & Substantive (+) & Difference \\
\hline Colonization & 109 & 47 & -62 \\
Revolution & 88 & 43 & -45 \\
Articles & 35 & 44 & +9 \\
Jacksonian & 46 & 38 & -8 \\
Slavery & 99 & 194 & +95 \\
Reconstruction & 77 & 44 & -33 \\
Industrialization & 114 & 63 & -51 \\
Imperialism/ & 74 & 84 & +10 \\
WWI & & & \\
Great Depression & 164 & 33 & -131 \\
WWII & 86 & 87 & +1 \\
Civil Rights & 102 & 23 & -79 \\
\hline
\end{tabular}

Compare the following thread with the previous examples from the Jacksonian unit:

Walter $^{6}$ : As a Southern planter I support slavery. The main points for my position are: 1) I am providing a safer and more secure environment for the African slave, 2) My slaves join my community on the plantation not so much as workers but as part of a larger family. I do not treat my slaves as property; 3) I treat my slaves humanely. I give them rewards, 4) Because the Bible does not condemn slavery it is alright to own slaves, 5) The slave is are freer than most Americans.

Allen (to Walter): I'll show you how your wrong in each point of supporting slavery:

1. You have no idea whether their way of life before being brought over here forcibly/by trickery was better or not. I don't think hard work and poor living conditions, death and torture are much better than cannibalism, and most slave 
owners did not feed them adequately enough, especially compared to their harsh workload. 'Besides, when the colonists first started bringing them over here, it was not their intent to make their life any better.

2. Just because you say they are equal, doesn't make it true. They can never even hope to be equal even if they are free. Just the fact that they are slaves deny them the three basic rights: life (many children died due to disease in poor living conditions), liberty (they were not free, they had to spend the whole day in the plantations, without breaks, and with no rights to say anything to their masters), pursuit of happiness (I would definitely not be happy as a slave)

3. Most slave owners treated them very poorly. They had very filthy living conditions and had disease and malnutrition that killed many children and were not treated with respect. They whipped them, even pregnant women, and even if you claim to be nicer than the next slave owner, that is not a very good excuse.

4. The Bible is the perfect literature against slavery; God made all humans equal, and should be treated equally. The Pharoah, who had thousands of slaves whipped them and ruled them and they had to work in the hot sun all day long, just for the Pharoah own wealth and power (sort of like the slaves in the 1850s) And the Pharoah was brought to justice by Moses (the abolitionists) and God.

5. They were just the opposite, they weren't comfortable at all, and were not free to do a thing. I don't think any kind of slave with no hope for any kind of future would have any kind of 'peace of mind' especially while working or being whipped.

Amy (to Allen): Slaves definitely didn't have a great life in the south, but it was better than living in the north. They just lived on streets and had no where to work, no where to live, or eat. They couldn't even go to church without being degraded. In the south they were guaranteed a life they could make due with and they were able to make peace with many people.

Allen (to Amy): I'm not against the North, just slavery. It was because of slavery that slaves were looked down upon in the North and didn't have anywhere to eat, sleep, etc. Even though the people were fighting slavery, they didn't like slaves or just thought they were inferior because of slavery.

Hunter (to Allen's $1^{\text {st }}$ post): In the Bible it does say that but people 
in the north own stores and they have people working for them and some of the owners do not treat their workers good. I mean you guys just don't call it slavery.

Cynthia (to Allen's $1^{\text {st }}$ post): There were many slave owners who made sure that the work loads that were given were fair and that people such as women, children, and the aged had less loads if any at all. Not all slave-owners treated their slaves poorly, for one their were often rewards for good work and behavior plus many treated them like family so they were very well take care of. Many slaves actually loved their owners very much too. And while I know in the bible it talks about equalness, there is also a lot of servants in the bible so you can't say the bible strictly says that slavery or servanthood is wrong.

Pete (to Allen's $1^{\text {st }}$ post): yes they may just be basic slaves, but just because they are slaves doesn't mean they can't have rights. They don't have rights because they are slaves, and they are slaves because southern plantes only care for themselves. They would even be here if you hadn't taken them from their home land and broke up their families

Jennifer (to Walter): I find the different accounts of slavery interesting. One side, the south, says that slaves were treated right and that they lived a better life. Conversely, based on what the abolitionists saw, slaves were treated like dirt and lived terrible lives. Personally, I would be much happier free, rather than enslaved, even if that meant less food and certainty of shelter. That is probably how many slaves and former slaves felt.

Pete: (to Walter): Slavery is morally wrong and physically wrong. People die every day because of the excusiating pain they are put through. Our founding fathers left England because the king treated them like slaves, but yet we are doing the same thing to these people.

While the placing of students into roles, particularly that of a plantation owner, may be unsettling for some, situating the discussion into a debate format using primary sources appeared to spark student creativity. In contrast to the Jacksonian threads, this discussion had several levels, and multiple conversations were being held simultaneously. More importantly, the primary sources allowed these students to partially reconstruct the slavery argument as it existed in the $19^{\text {th }}$ century, a fact that Jennifer notes in her summary of the dialogue up to that point. 
When asked how they liked the slavery discussion, nearly all of the students claimed to have enjoyed the debate. Alex specifically mentioned the use of primary sources, citing that the resources made it "easier to debate and bring up a lot of arguments." Cynthia seemed to agree, and stated that she enjoyed the debate because it "kind of got people to write more." The only negative comments about the debate came from three students who were assigned as plantation owners and complained that they were forced to defend a position they did not advocate.

To summarize, then, the asynchronous communication was not very effective in facilitating substantive historical discussions among adolescents. Several factors appeared to affect the quality of historical discussions, in particular, unequal participation among students and a general lack of historical knowledge displayed in student posts. For his part, Mr. Harding did little to increase the quality of discussion in the course. Despite stating that he valued interaction among students, Mr. Harding rarely enforced guidelines designed to encourage richer discussion, seemed to lose interest in monitoring the discussion board after the second unit, and failed to adequately communicate expectations to his students. This inaction on the part of $\mathrm{Mr}$. Harding raises issues about teaching history to adolescents in online environments, the implications of which are discussed in the following section.

\section{Discussion}

Although all of the students in the class passed the course and may have learned enough facts to pass the state assessment, the discussion board interactions suggest that the social component of the course did little to enhance the students' ability to discuss historical content or gain multiple perspectives of historical events. From a social constructivist standpoint, that part of the course must be considered a disappointment, and part of the blame must be directed at the inability of Mr. Harding to create a substantial dialogue among his students. Although this case offers only one example of K-12 social studies online instruction, I feel that several lessons can be drawn from the results of this study. I outline four such implications below.

\section{Lesson One: Adolescents Cannot Be Expected to Initiate and Carry Sophisticated Historical Conversations Asynchronously Without Teacher Support}

Perhaps the greatest detriment to the quality of the course discussion was the fact that the students were left, for the most part, on their own to initiate, perpetuate, and regulate the historical 
conversation in each unit. Such a task would be daunting to most high school students who are not historians by trade and view thinking historically as an unnatural act (Wineburg, 2001). For high school students largely uninterested in history, taking an expedited summer class in the midst of vacation, and lacking the comfort of knowing their classmates, such a task is nearly impossible. What occurred were responses posted for the sake of posting, few assertions backed by evidence, and a general lack of challenging others' beliefs. In other words, it seems as if the students were talking at each other rather than with each other on the discussion boards.

The presence of an instructor, particularly at the beginning of the course, may have helped bridge the gap between their unsophisticated knowledge of history and the ability to engage in sound historical discussions (Vygotsky, 1978). The lack of attention paid to the course discussion board by $\mathrm{Mr}$. Harding reinforces previous findings that suggest teacher monitoring of asynchronous communication is essential to creating a constructive learning environment (Berge, 2002; Maor, 2003). Clearly, Mr. Harding did not effectively assume this role; however, his reasoning is not as evident. It is certainly possible that $\mathrm{Mr}$. Harding, like his students, balanced the course between vacations and other summer responsibilities and was content to have his students just learn enough to pass the state assessment. However, his teaching philosophy and apparent dismay at the state of the discussion board suggest otherwise.

Anexplanation that seems more plausible relates to Mr. Harding's opinions of online students and his lack of confidence in e-learning as an appropriate medium for learning history. Based on his past experiences teaching the online course, Mr. Harding characterized online students as academically disengaged and unwilling to actively participate in the discussion board. The fact that Mr. Harding normally teaches AP students during the regular school year may also heighten this perception. It is possible that his characterization of "online students" is actually a depiction of typical high school students.

The actions of his students at the beginning of the course did nothing to sway these opinions. It is probably not a coincidence that Mr. Harding's participation in the discussion board steadily declined after none of his students responded to his posts in that first unit. It seems possible that Mr. Harding believed that he would be wasting his time continuing to post comments to disinterested students in later units. This conclusion is strengthened when one considers that three of Mr. Harding's four posts after the second unit were initiated toward Cynthia, the student Mr. Harding believed put forth the most effort in the discussion board. 


\section{Lesson Two: Many of the Techniques to Effectively Moderate Asynchronous Discussions are the Same as Moderating Classroom Discussions}

Any successful teacher knows that effective instruction involves implementing and enforcing clear guidelines for students to follow. Mr. Harding seemed to recognize the need to set guidelines for discussion, yet he did not effectively reinforce those rules throughout the course. A 250-word requirement may have forced students to think critically about their posts in an effort to find evidence to back their assertions. However, few of the students routinely met this standard, and the evidence suggests that Mr. Harding did not attempt to rectify the problem.

Mr. Harding also never provided an example of an effective historical argument for students to emulate, an essential feature of successful asynchronous discussions according to Maor (2003). Moreover, in his email communication to Brandon's parents, he pointed to Cynthia as the best example in the class but went on to suggest that even she was not meeting his standards for a quality historical argument. Therefore, at no point during the span of the course did students have an example of Mr. Harding's ideal historical argument. As Passe and Evans (1996) note, one of the responsibilities of teachers when leading issue-based discussions is to model appropriate actions for students. Perhaps the students would have benefited from direct instruction on how to formulate historical arguments prior to discussing a specific topic on the discussion board.

However, one teacher intervention that may have increased both student participation and argument construction was giving students access to primary sources. As in the classroom, students cannot be expected to make sophisticated arguments without evidence to confirm or contradict the preconceived notions that they have regarding historical events (Wineburg, 2001). Although having students assume the role of a slave owner may push the limits of historical empathy, providing primary sources to students seemed to give students ammunition for their claims; greatly increasing the number of opinions backed by historical evidence in that unit. However, since Mr. Harding only gave students primary sources in that one unit, it is impossible to draw strong conclusions about the effect of outside sources in asynchronous discussions because student participation may have been bolstered by the novelty of the assignment.

The slavery unit was also unique from a discussion standpoint. However, Parker and Hess (2001) are clear that, according to their typology, debates are not a true form of deliberation due to the adversarial component that often keeps students from truly listening to the other side, the slavery debate contained more deliberative 
elements than any of the other discussion board prompts that simply asked students to reflect on a historical issue. The majority of the class did not seem overly interested in others' opinions during the course and certainly did not appear to actively read and reflect on others' posts when formulating their own opinions in the discussion board. However, when presented with the goal of "winning the debate" in the slavery unit, the students seemed to value their classmates' opinions, if only to search for evidence to bolster their own opinions. The increased participation and number of substantive statements found in the slavery unit raises questions of how best to structure prompts in order to achieve higher-quality historical discussions in an asynchronous format. Perhaps assignments that require students to discuss for the purpose of coming to a conclusion about a specific historical issue may be more effective than a seminar approach that only encourages exploration and understanding of a particular issue. Again, the lone example of debate in the course necessitates future research in order to move this conclusion beyond mere speculation.

\section{Lesson Three: E-Learning Teachers Must Attempt to Communicate with Students through Multiple Means}

While many of the basic strategies for leading discussions are the same online as in the classroom, e-learning teachers have to deal with issues that classroom teachers never face. When dealing with students online, teachers do not have access to the nonverbal communication that alerts teachers to topics that need additional coverage or leave students disinterested. At the same time, asynchronous discussion represents an unstructured environment which may be unfamiliar for students. Choices of which threads to read, which discussion to join, and how to change discussion topics may be daunting to students who normally rely on their teacher to facilitate such actions.

One misconception of teaching online is that it is easier and time efficient; however, in order to reach levels of teacher-student interaction that are comparable to the classroom, online instructors probably need to spend even more time and energy in developing connections (Tomei, 2006). Therefore, e-learning teachers need to spend additional time monitoring discussions and interacting with students, even outside course discussion forums. The email data seem to represent a missed opportunity for Mr. Harding. The fact that over 100 emails were exchanged in five weeks speaks to the potential of email communication as a way to bridge the gap between student and teacher. However, in this course, email was reduced to tech support and a way for Mr. Harding to remind students to turn in work.

Another communication option that was not utilized in this course would be for teachers to hold virtual office hours using email 
or synchronous software, such as an instant messenger program, where students could contact the instructor directly and receive the immediate feedback they may desire (Rovai, 2000). Teachers could even require student participation in at least one synchronous chat session with their classmates per week where the fluid pace of discussion may allow teachers to revisit topics that were not fully explored asynchronously or prime topics that will take place in an upcoming unit. Further, in a study of an online library science course that utilized both synchronous and asynchronous communication, Haythornthwaite, Kazmer, Robins, and Shoemaker (2004) found that students valued the personal freedom afforded by asynchronous discussion but often relied on synchronous chats to build relationships with classmates and explore a wide variety of topics. Although a weekly synchronous requirement may have been impractical in this particular case due to the traveling done by both Mr. Harding and his students during the course, it may have been useful as a supplement to the discussion board assignments.

\section{Lesson Four: Asynchronous Communication Must Be Made Manageable for Students}

As Larson (2003) found, reading posts in an asynchronous format takes considerably more time than engaging in classroom discussions. This time demand seemed particularly problematic for Mr. Harding's students who were only given two days to complete each unit. That amount of time does not give students many opportunities to revisit the discussion board before moving to subsequent units. Moreover, when students wait until the deadline to make their initial posts, it makes replying to those posts nearly impossible.

While Mr. Harding did not control the timing of the course, he did control the format of the discussion board. One way he could have remedied the time situation would be to require students to make their initial posts by a certain point and then make their replies soon thereafter. Such a schedule would have allowed Mr. Harding to start a dialogue with students by replying to students' initial posts before they revisited the discussion board to post their replies. Another option would be to have small group discussions that rotated with each unit. This way, students would only have to read and reply to three or four posts in each unit instead of being overwhelmed at the prospect of 13 different threads. In addition, rotating the groups for each unit guarantees that all students would be exposed to the differing perspectives held by each member of the class. 


\section{Conclusion}

While it may be easy to assail Mr. Harding for the poor quality of historical discussion found in this course, it would be wise to remember that $\mathrm{K}-12$ e-learning is still in its infancy. Teachers like Mr. Harding are often placed into virtual environments based on their success in the classroom and given few guidelines on how to effectively teach online. As technology continues to improve and more districts begin to experiment with online programs, I concur with Davis and Roblyer (2005) that teacher training programs must prepare the next generation of teachers for the possibility of online instruction. Although this study found asynchronous discussion a poor format for facilitating historical dialogue, future changes in the way social studies teachers approach electronic communication may change that notion. Further research on the relationship between $\mathrm{K}-12$ e-learning and content is needed for the continued improvement of online instruction. 


\section{Appendix A}

\section{Interview Protocol for Mr. Harding}

1. How long have you been teaching online?

2. Can you please explain your teaching philosophy for online courses?

3. Does your teaching philosophy for online instruction differ from your philosophy for classroom instruction?

4. What do you think the students' instructional goals are in the online class?

5. What strategies do you use to push the social component in the online class?

6. How do you perceive your role in the online classroom?

7. How does your role differ in the online classroom versus your regular classroom?

8. How would you characterize your relationship with your online students?

9. How important do you think it is for students to discuss historical issues?

10. Do you make requirements for your online students with regard to number of postings or word limits? 


\section{Appendix B}

\section{Interview Protocol for Students}

1. How do you feel the course is going?

2. Why did you decide to take U.S. history online?

3. Where does history rank in your favorite subjects?

4. What aspect of the course do you like the most? Why?

5. What aspect of the course do you like the least? Why?

6. How would you characterize your relationship with Mr. Harding?

7. How do you feel about the discussion board?

8. Do you feel you frequently respond to your classmates' posts on the discussion board?

9. How many of your classmates' posts do you read in each unit?

10. How do you choose which of your classmates' posts to read in each unit?

11. What do you get out of reading your classmates' posts?

12. Do you ever go back and look to see if Mr. Harding or one of your classmates has ever replied to one of your posts?

13. If so, what keeps you from responding back to that person?

14. How would you characterize your relationship with the other members of the class?

15. How would you characterize your learning of American history in this course? 


\section{Appendix C}

Primary Sources Used in Slavery Debate

\begin{tabular}{|c|c|c|}
\hline Links Supporting Slavery & & \\
\hline $\begin{array}{l}\text { James Henry Hammond } \\
\text { Speech to U.S. Senate }\end{array}$ & http://www.pbs.org/wgbh/aia/part4/4h3439t.html & \\
\hline $\begin{array}{l}\text { "The Universal Law of } \\
\text { Slavery" by George Fitzhugh }\end{array}$ & http://www.pbs.org/wgbh/aia/part4/4h3141t.html & . \\
\hline $\begin{array}{l}\text { Article from The Spectator } \\
1 / 17 / 1860\end{array}$ & $\begin{array}{l}\text { http://teacherlink.org/content/social/instructional/ } \\
\text { defense/proslavewsht3.html }\end{array}$ & \\
\hline $\begin{array}{l}\text { Article from The Spectator } \\
12 / 6 / 1859\end{array}$ & $\begin{array}{l}\text { http://teacherlink.org/content/social/instructional/ } \\
\text { defense/proslavewsht } 2 . h t m l\end{array}$ & \\
\hline $\begin{array}{l}\text { Interview with William } \\
\text { Scarborough }\end{array}$ & http://www.pbs.org/wgbh/aia/part4/4i3101.html & \\
\hline
\end{tabular}

\begin{tabular}{ll}
\hline Links Against Slavery & \\
\hline $\begin{array}{l}\text { Excerpt from Journal of } \\
\text { a Residence on a Georgia }\end{array}$ & http://www.pbs.org/wgbh/aia/part4/4h2922t.html \\
$\begin{array}{l}\text { Plantation } \\
\text { Image of a Slave with Iron }\end{array}$ & http://www.pbs.org/wgbh/aia/part1/1h308.html \\
Muzzle & \\
& \\
Image of a Slave Hung at the & http://www.pbs.org/wgbh/aia/part1/1h294.html \\
Gallows & http://www.pbs.org/wgbh/aia/part4/4h1540.html \\
Image of Slave Quarters & http://www.pbs.org/wgbh/aia/part4/4p2920.html \\
Butler Island: 1839 & http://www.spartacus.schoolnet.co.uk/ \\
Image of Whipping Scars & USASwhipping.jpg \\
& \\
&
\end{tabular}


${ }^{1}$ All identifying information about the teacher, students, and district has been changed to protect participants' identities.

${ }^{2}$ The course contained one exception to this rule. The Cold War Unit did not utilize a discussion board assignment.

${ }^{3}$ The e-learning coordinator interview provided background information about the program and Mr. Harding's experience. Readers interested in the actual questions asked of the e-learning coordinator can contact the author.

${ }^{4}$ Two of the students, Beth and Randi, did not volunteer to be interviewed. Coincidentally, these two students maintained technical problems throughout the course and, therefore, had limited access to the discussion board and rarely interacted with the other students in the course. Their discussion assignments were submitted directly to Mr. Harding via email or the Blackboard digital drop box.

${ }^{5}$ None of the posts from students and Mr. Harding have been changed to improve grammar or spelling.

${ }^{6}$ For the sake of brevity I am only including the main points of Walter's post. Walter extensively backed each point with verbatim quotations from the primary source material.

\section{References}

Anderson, R. C., Nguyen-Jahiel, K., McNurlen, B., Archodiou, A., Kim, S., Reznitskaya, A. et al. (2001). The snowball phenomenon: Spread of ways of talking and ways of thinking across groups of children. Cognition and Instruction, 19, 1-46.

Berge, Z. L. (2002). Active, interactive, and reflective learning. Quarterly Review of Distance Education, 3, 181-190.

Berge, Z. L. (2005). Taking the distance out of distance education. In G. Kearsley (Ed.), Online learning: Personal reflections on the transformation of education (pp. 12-25). Englewood Cliffs, NJ: Educational Technology Publications.

Berger, P. L., \& Luckman, T. (1966). The social construction of reality: A treatise in the sociology of knowledge. Garden City, NJ: Doubleday.

Blaylock, T. H., \& Newman, J. W. (2005). The impact of computer-based secondary education. Education, 125, 373-384.

Bolinger, K., \& Warren, W. J. (2007). Methods practiced in social studies instruction: A review of public school teachers' strategies. International Journal of Social Education, 22(1), 68-84.

Bruce, B. C. (2004). Maintaining the affordances of traditional education long distance. In C. Haythornthwaite \& M. M. Kazmer (Eds.), Learning, culture and community in online education: Research and practice (pp. 19-32). New York: Peter Lang.

Burbules, N.C. (2004). Navigating the advantages and disadvantages of online pedagogy. In C. Haythornthwaite \& M. M. Kazmer (Eds.), Learning, culture and community in online education: Research and practice (pp. 3-17). New York: Peter Lang.

Chinn, C. A., \& Anderson, R. C. (1998). The structure of discussions that promote reasoning. Teachers College Record, 100, 315-368.

Chyung, S. Y., \& Vachon, M. (2005). An investigation of the profiles of satisfying and dissatisfying factors in e-learning. Performance Improvement Quarterly, 18, 97-113.

Conceicao, S., \& Drummond, S. B. (2005). Online learning in secondary education: A new frontier. Educational Considerations, 33, 31-37.

Crotty, M. (1998). The foundations of social research: Meaning and perspective in the research process. London: Sage.

Davidson-Shivers, G. V., Morris, S. B., \& Sriwongkol, T. (2003). Gender differences: Are they diminished in online discussions? International Journal on E-Learning, 2, 2936.

Davies, J., \& Graff, M. (2005). Performance in e-learning: Online participation and student grades. British Journal of Educational Technology, 36, 657-663. 
Davis, N. E., \& Roblyer, M. D. (2005). Preparing teachers for the "schools that technology built": Evaluation of a program to train teachers for virtual schooling. Journal of Research on Technology in Education, 37, 399-409.

Dewstow, R., \& Wright, N. (2005). Secondary school students, online learning, and external support in New Zealand. Computers in the Schools, 22, 111-122.

Donmoyer, R. (1990). Generalizability and the single-case study. In E. W. Eisner \& A. Peshkin (Eds.), Qualitative inquiry in education: The continuing debate (pp. 175-200). New York: Teachers College Press.

Doolittle, P. E., \& Hicks, D. (2003). Constructivism as a theoretical foundation for the use of technology in social studies. Theory and Research in Social Education, 31, 71-103.

Fontana, A., \& Frey, J. H. (2005). The interview: From neutral stance to political involvement. In N. K. Denzin \& Y. S. Lincoln (Eds.), The Sage handbook of qualitative research (3rd ed., pp. 695-728). Thousand Oaks, CA: Sage.

Fosnot, C. T. (2005). Constructivism revisited: Implications and reflections. In C. T. Fosnot (Ed.), Constructivism: Theory, perspectives, and practice (2nd ed., pp. 276-291). New York: Teachers College Press.

Fosnot, C. T., \& Perry, R. S. (2005). Constructivism: A psychological theory of learning. In C. T. Fosnot (Ed.), Constructivism, theory, perspectives, and practice (2nd ed., pp. 8-38). New York: Teachers College Press.

Garrison, D. R., \& Anderson, T. (2003). E-learning in the 21st century: A framework for research and practice. London: RoutledgeFalmer.

Gergen, K. J. (1995). Social construction and the educational process. In L. P. Steffe \& J. Gale (Eds.), Constructivism in education (pp. 17-39). Hillsdale, NJ: Lawrence Earlbaum Associates.

Grant, S. G. (2003). History lessons: Teaching, learning, and testing in U.S. high school classrooms. Mahwah, NJ: Lawrence Earlbaum Associates.

Hadjioannou, X. (2007). Bringing the background to the foreground: What do classrooms environments that support authentic discussions look like? American Educational Research Journal, 44, 370-399.

Haythornthwaite, C., \& Bregman, A. (2004). Affordances of persistent conversation: Promoting communities that work. In C. Haythornthwaite \& M. M. Kazmer (Eds.), Learning, culture and community in online education: Research and practice (pp. 129143). New York: Peter Lang.

Haythornthwaite, C., Kazmer, M. M., Robins, J., \& Shoemaker, S. (2004). Community development among distance learners: Temporal and technological dimensions. In C. Haythornthwaite \& M. M. Kazmer (Eds.), Learning, culture and community in online education: Research and practice (pp. 35-57). New York: Peter Lang.

Hazari, S. (2004). Strategy for assessment of online course discussions. Journal of Information Systems Education, 15, 349-355.

Herring, L. C., \& Clevenger-Schmertzing, L. (2007). Online high school world history: Does interaction make a difference? Social Studies Research and Practice, 2, 419-437.

Kapitzke, C., \& Pendergast, D. (2005). Virtual schooling service: Productive pedagogies or pedagogical possibilities? Teachers College Record, 107, 1626-1651.

Kickul, G., \& Kickul, J. (2006). Closing the gap: Impact of student productivity and learning goal orientation on e-learning outcomes. International Journal on E-Learning, 5, 361-372.

Larreamendy-Joerns, J., \& Leinhardt, G. (2006). Going the distance with online education. Review of Educational Research, 76, 567-605.

Larson, B. E. (2003). Comparing face-to-face discussion and electronic discussion: A case study from high school social studies. Theory and Research in Social Education, 31, 347-365.

Larson, B. E. (2005). Considering the move to electronic discussions. Social Education, $69,162-166$.

Lave, J., \& Wenger, E. (1991). Situated learning: Legitimate peripheral participation. Cambridge, UK: Cambridge University Press. 
Lee, P. (2004). Understanding history. In P. Seixas (Ed.), Theorizing historical consciousness (pp. 129-164). Toronto: University of Toronto Press.

Lincoln, Y. S., \& Guba, E. G. (1985). Naturalistic inquiry. Newbury Park, CA: Sage.

Lyons, J. F. (2004). Teaching U.S. history online: Problems and prospects. The History Teacher, 37, 447-456.

Maor, D. (2003). The teacher's role in developing interaction and reflection in an online learning community. Educational Media International, 40, 127-137.

Maxwell, J. (1992). Understanding and validity in qualitative research. Harvard Educational Review, 62, 279-300.

Merriam, S. B. (1998). Qualitative research and case study applications in education. San Francisco, CA: Jossey-Bass.

Merryfield, M. M. (2000). Using electronic technologies to promote equity and cultural diversity in social studies and global education. Theory and Research in Social Education, 28, 502-526.

Michigan Department of Education. (2006). Michigan Merit Curriculum guidelines. Accessed at http://www.techplan.org/Online\%20Exerience $\% 20$ Guidelines $\% 20$ 2006.pdf

Molebash, P. E. (2002). Constructivism meets technology integration: The CUFA technology guidelines in an elementary social studies methods course. Theory and Research in Social Education, 30, 429-455.

Newmann, F. M., \& Wehlage, G. G. (1993). Five standards of authentic instruction. Educational Leadership, 50(7), 8-12.

Noble, D. 'F. (2001). Digital diploma mills: The automation of higher education. New York: Monthly Review Press.

Nystrand, M., Gamoran, A., \& Carbonaro, W. J. (2001). On the ecology of classroom instruction: The case of writing in high school English and social studies. In P. Tymjala, L. Mason, \& K. Lonka (Eds.), Writing as a learning tool (pp. 57-81). Norwell, MA: Kluwer Academic Publishers.

Onosko, J. J. (1990). Comparing teachers' instruction to promote students' thinking. Journal of Curriculum Studies, 22, 443-461.

Parker, W. C. (2006). Public discourses in schools: Purposes, problems, possibilities. Educational Researcher, 35(8), 11-18.

Parker, W. C., \& Hess, D. (2001). Teaching with and for discussion. Teaching and Teacher Education, 17, 273-289.

Passe, J., \& Evans, R. W. (1996). Discussion methods in an issues-centered curriculum. In R. W. Evans \& D. W. Saxe (Eds.), Handbook on teaching social issues (pp. 81-88). Washington, DC: National Council for the Social Studies.

Postman, N. (2000). Will our children only inherit the wind? Theory and Research in Social Education, 28, 580-586.

Reznitskaya, A, \& Anderson, R. C. (2002). The argument schema and learning to reason. In C. C. Block \& M. Pressley (Eds.), Comprehension instruction (pp. 319-334). New York: Guilford Press.

Richardson, V. (2003). Constructivist pedagogy. Teachers College Record, 105, 1623-1640.

Roblyer, M. D. (1999). Is choice important in distance learning? A study of student motives for taking internet-based courses at the high school and community college levels. Journal of Research on Computing in Education, 32, 157-171.

Roblyer, M. D., \& Marshall, J. C. (2002). Predicting the success of virtual high school students: Preliminary results from an educational success prediction instrument. Journal of Research on Technology in Education, 35, 241-255.

Rovai, A. P. (2000). Building and sustaining community in asynchronous learning networks. Internet and Higher Education, 3, 285-297.

Rovai, A.P. (2001). Building classroom community at a distance: A case study. Educational Technology Research and Development, 49(4), 33-48.

Schrum, L. (2004). The web and virtual schools. Computers in the Schools, 21, 81-89. 
Schwandt, T. A. (1994). Constructivist, interpretivist approaches to human inquiry. In N. K. Denzin \& Y. S. Lincoln (Eds.), Handbook of qualitative research (pp. 118-137). Thousand Oaks, CA: Sage.

Schwandt, T. A. (2003). Three epistemological stances for qualitative inquiry: Interpretivism, hermeneutics, and social constructionism. In N. K. Denzin \& Y. S. Lincoln (Eds.), The landscape of qualitative research: Theories and issues (2nd ed., pp. 292-331). Thousand Oaks, CA: Sage.

Seixas, P. (1993). The community of inquiry as a basis of knowledge and learning: The case of history. American Educational Research Journal, 30, 305-324.

Stake, R. E. (1995). The art of case study research. Thousand Oaks, CA: Sage.

Tally, B. (2007). Digital technology and the end of social studies education. Theory and Research in Social Education, 35, 305-321.

Tomei, L. A. (2006). The impact of online teaching on faculty load: Computing the ideal class size for online courses. Journal of Technology and Teacher Education, 14, 531541 .

Vygotsky, L. S. (1978). Mind in society: The development of higher psychological processes. Cambridge, MA: Harvard University Press.

Wenger, E. (1998). Communities of practice: Learning, meaning, and identity. Cambridge, UK: Cambridge University Press.

Wineburg, S. S. (1991). Historical problem solving: A study of the cognitive processes used in the evaluation of documentary and pictorial evidence. Journal of Educational Psychology, 83, 73-87.

Wineburg, S. S. (2001). Historical thinking and other unnatural acts: Charting the future of teaching the past. Philadelphia, PA: Temple University Press.

Yin, R. K. (1994). Case study research: Design and methods (2nd ed.). Thousand Oaks, CA: Sage.

WAYNE JOURNELL is a doctoral candidate in the College of Education at the University of Illinois at Urbana-Champaign, Champaign, IL, 61820. He can be contacted at: ajourne2@illinois.edu 